\title{
Architecture for Customer Relationship Management Approaches in Financial Services
}

\author{
Malte Geib, Annette Reichold, Lutz Kolbe, Walter Brenner \\ Institute of Information Management, University of St. Gallen \\ Malte.Geib|Annette.Reichold|Lutz.Kolbe|Walter.Brenner@unisg.ch
}

\begin{abstract}
The majority of financial services companies in Germany and Switzerland have, with varying objectives and success, conducted customer relationship management (CRM) implementation projects.

In this paper we present a framework for the analysis of CRM approaches in financial services companies. Building on previous research and using comprehensive literature research, we develop a CRM reference architecture that focuses on the process and system level for the description and classification of CRM approaches in companies. Moreover, we analyze three CRM case studies in Swiss and German financial services companies and derive different types of CRM approaches in the financial services industry: Customer Satisfaction Management, Customer Contact Management, and Customer Profitability Management. We describe each type in accordance with the CRM architecture and a case example.
\end{abstract}

Keywords: Customer Relationship Management, Knowledge Management, Performance Management.

\section{Introduction}

Increasing competition and decreasing customer loyalty have led to the emergence of Customer Relationship Management (CRM), a concept that focuses on the nurturing of customer relationships. To build long lasting, profitable relationships with customers, CRM requires the management of 'customer-related knowledge' which entails knowledge from, about and for customers [2][5].

Over the past few years CRM has played an increasingly important role in the financial services industry. During this time the majority of financial services companies in Germany and Switzerland have, with varying success, conducted CRM implementation projects. Only a few companies have particularly realized the implementation of a CRM strategy aligned with company profitability and employing integrated information systems for both performance measurement as well as for the control of marketing, sales, and service processes [22].

The objectives of this contribution are

1. the development of a CRM reference architecture on the process and systems levels for the description and classification of CRM approaches in financial services companies, and

2. the derivation of the types of CRM approaches in the financial services industry and their description by means of the CRM architecture.

The developed CRM architecture and defined CRM types can be used in the analysis of CRM in companies to determine the actual state and to define a target state.

In the next section we describe the foundations and strategic objectives of CRM. We thereafter develop the CRM architecture for the process and system levels. Thus, we provide an holistic picture of CRM over the levels strategy, processes and information systems [11]. In the third section we describe our case study sites, as well as the results of our analysis in the form of three CRM types. Section four concludes with a summary, a critical reflection of the results, and further research opportunities.

\section{Customer Relationship Management in the financial services industry}

The following paragraphs describe CRM on the levels of strategy, processes and information systems.

\subsection{Strategic objectives}

Decreasing customer loyalty in different industries has led to the emergence of concepts that focus on the 
nurturing of customer relationships [13][14], in particular Customer Relationship Management (CRM). Following Shaw and Reed [20, p. 4], we define CRM as an interactive approach that achieves an optimum balance between corporate investments and the satisfaction of customer needs in order to generate maximum profits. This entails:

- acquiring and continuously updating knowledge on customer needs, motivations, and behavior over the lifetime of the relationship.

- applying customer knowledge to continuously improve performance through a process of learning from successes and failures.

- integrating marketing, sales, and service activities to achieve a common goal.

- the implementation of appropriate systems to support customer knowledge acquisition, sharing, and the measurement of CRM effectiveness. processes that involve customers. These customeroriented CRM processes are mostly semi-structured, i.e., they involve activities that cannot be described formally and therefore cannot be automated completely. Their performance is predominantly influenced by the underlying supply of knowledge on products, markets, and customers [3][4][17]. CRM processes can therefore be considered as knowledgeintensive processes. Managing the collection, storage and distribution of relevant knowledge requires the use of Knowledge Management (KM) in CRM processes. „Knowledge Management is the process of critically managing knowledge to meet existing needs, to identify and exploit existing and acquired knowledge assets and to develop new opportunities." [16] The following section describes CRM and KM processes and the closed knowledge loop that should be achieved in CRM to exploit its potential.

To integrate marketing, sales, and service activities, CRM requires the strong integration of business

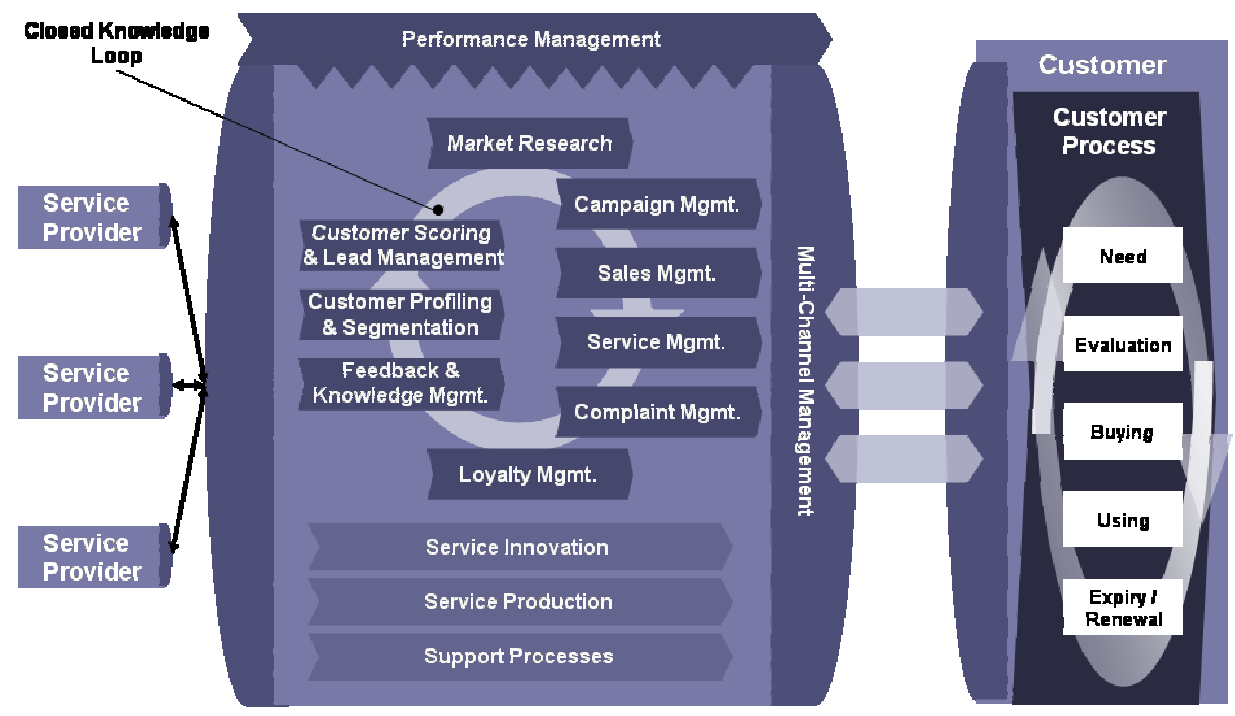

Figure 1. Customer relationship management architecture (process level).

\subsection{Processes}

The architecture presented is the further development of an earlier architecture developed in a joint research project with several German and Swiss financial services companies [5][6]. The architecture is based on literature research and was discussed and validated in four team workshops of eight CRM and
KM researchers and in two two-day workshops with six financial services companies.

The process level (Figure 1) incorporates business processes that are regarded as relevant to CRM in most of the literature analyzed. The system level (section 2.3.) depicts information systems relevant to CRM and their relationships to one another.

An important aspect of CRM is its orientation to customer processes (or Customer Resource Lifecycles, 
CRLC) [cf. 9, p. 1197]. A customer process is the sequence of activities that a customer has to perform to satisfy a need or to solve a specific problem, e.g., building a house. A customer process therefore determines the required products and services that a service provider has to offer to cover a customer process entirely [12, p. 25]. Because most service providers cannot cover an entire customer process, or do not want to cover it due to a focus on certain core competencies, collaboration with other service providers that offer complementary products and services is necessary.

We distinguish among three categories of CRM processes:

- CRM delivery processes: Processes with direct customer contact that are designed to cover part of the customer process (campaign management, sales management, service management, complaint management).

- CRM support processes: Processes with direct customer contact that are not designed to cover part of the customer process, but to fulfill supporting functions within the CRM context (market research, loyalty management).

- CRM analysis processes: Processes that consolidate and analyze customer knowledge that has been collected in other CRM processes. The analysis results are passed on to the CRM delivery and support processes as well as to the service innovation and service production processes to improve their effectiveness (customer scoring and lead management, customer profiling and segmentation, feedback and knowledge management).

Next, we provide a short overview of each CRM process.

\section{CRM delivery processes}

In contrast with transaction marketing, relationship marketing is based on interactive, individualized contacts [8, p. 11]. Campaign management is the core marketing process that implements relationship marketing's ideas. We define it as the planning, realization, control, and monitoring of marketing activities aimed at known recipients, who are either current or prospective customers. Marketing campaigns are individualized (one-to-one marketing) [15] or segment-specific, usually use different communication channels, and offer at least one communication channel for feedback from the recipients to allow interaction.
The objective of campaign management is to generate valuable opportunities or 'leads', which can be further qualified by lead management and then used by sales management. Campaign management addresses the need articulation phase of the customer process.

The objectives of sales management are to understand the needs of a current or prospective (but known) customer as completely as possible, to consult the customer on possible alternatives with which to satisfy his needs, and finally to submit an offer, and close a deal. Therefore sales management covers the customer process phases of need articulation, evaluation, and buying.

Service and complaint management cover the customer process phases of using and expiry / renewal of a service contract complementarily. Service management is the planning, realization and control of measures for the provision of services. Examples include contract management and information services in the after-sales phase.

Customers' articulated dissatisfaction is received, processed, and communicated in the enterprise within the scope of complaint management [21]. The objectives are to improve customer satisfaction in the short-run by directly addressing problems that led to complaints, and to support a continuous improvement process (in the form of feedback management) to avoid complaints in the long-run. Complaint management primarily addresses the using phase of the customer process.

\section{CRM support processes}

Market research is the systematic design, collection, analysis, and reporting of data and findings relevant to a specific marketing situation facing the company [10, p. 129].

Loyalty management is the planning, realization, control, and monitoring of measures to optimize the duration and intensity of relationships with customers. Exemplary measures are loyalty programs such as airlines' frequent flyer programs, but also churn management to identify customers who are in danger of migrating to competitors at an early stage.

\section{CRM analysis processes}

Lead management is the consolidation, qualification, and prioritization of contacts with prospective customers. Contacts may be received from campaign management or other sources, e.g., the 
service management process. The objective is to provide sales staff with a qualified and prioritized list of presumably valuable prospective customers to allow them to be precisely and effectively addressed within the sales management process. In contrast to lead management, the objective of customer scoring is to prepare a list of current customers who may be interested in a specific product or service. Thereby, customer scoring takes advantage of the cross-selling potentials of current customers and offers a means with which to address customers more precisely to decrease contact costs and increase customer satisfaction.

Customer profiling is the analysis of current knowledge about customers in order to classify and characterize each customer, for example with regard to his value for the company, loyalty, and preferences regarding products and communication channels. Campaign management, sales management, service management, complaint management, and loyalty management processes use the results of customer profiling to address customers in a more personalized way. Conversely, the objective of segmentation is the development of homogenous customer segments that have different product and service needs $[10$, p. 9]. Customer segments are the basis for the development of variants in a company's product and service portfolio.

Feedback management is responsible for the consolidation and analysis of knowledge from customers, which is collected in the CRM delivery processes, particularly in the complaint management process. The results feed a continuous improvement process of a company's products, services and processes.

Multi-channel management is a cross-functional activity and is responsible for the synchronization of the CRM delivery and support processes. It is the coordinated development, design and control of product and knowledge flows to and from customers over different media and communication channels [7, p. 19].

For effective CRM, the implementation of a closed knowledge loop is essential. Knowledge about customers that is collected in the CRM delivery and support processes has to be passed on to the analysis processes. It is analyzed there and the results are channeled back to the delivery and support processes in the form of recommendations for action. To increase effectiveness, only knowledge that is needed to make recommendations should be collected and analyzed.

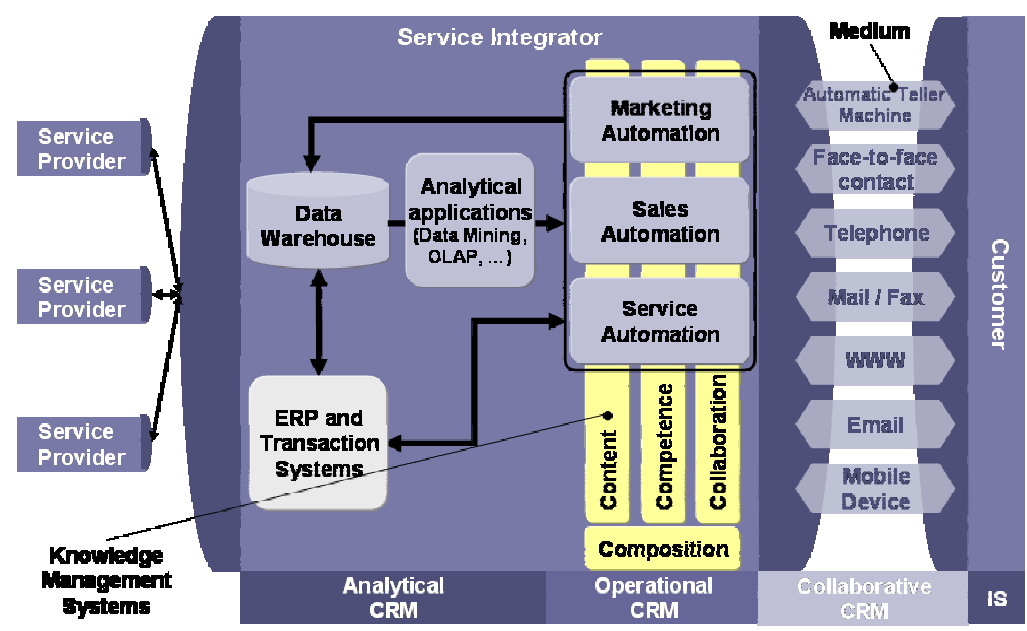

Figure 2. Customer relationship management architecture (system level).

Performance management is the management process for all CRM processes. It enables the integrated control and monitoring of, as well as the resource allocation to the CRM processes as described by Shaw and Reed [20]. The foundation of performance management is an activity-based costing $(\mathrm{ABC})$ to determine the profit contribution made by the customers and activities within the scope of the CRM processes.

After the description of CRM processes, we now turn to the necessary information systems to support these processes. 


\subsection{Systems}

On the system level we differentiate between three categories of information systems that are relevant to CRM (Figure 2): CRM systems, knowledge management $(\mathrm{KM})$ systems, and enterprise resource planning (ERP) and transaction systems.

According to the Metagroup, CRM systems can be classified into the following three sub-categories [19]:

- Operational CRM systems improve the efficiency of CRM delivery and support processes. They comprise solutions for marketing, sales and service automation, e.g., campaign management systems and systems for customer interaction centers.

- Analytical CRM systems store and evaluate knowledge about customers for a better understanding of each customer and his behavior. They therefore support the CRM analysis processes. Examples are data warehousing, online analytical processing (OLAP) and data mining systems.

- Collaborative CRM systems manage and synchronize customer interaction points and communication channels (e.g. telephone, email, and web).

CRM systems essentially process well-structured information, e.g., customer contact data and master data. In contrast, KM systems support the collection, sharing, and use of less-structured information such as documents (explicit knowledge) and employees' implicit knowledge [1]. This knowledge is especially needed in the CRM delivery processes to satisfy customer needs. For example, the sales management needs detailed knowledge of the products available in order to offer customers effective consultation in respect of their needs. We distinguish between four categories of KM systems [6, p. 404]:

- Content: This category comprises systems for the management, sharing, and use of semi-structured, digital content, in particular document management systems (DMS) and content management systems (CMS).

- Competence: This category comprises systems for the proactive management and location of implicit knowledge in employees' minds. To support the utilization and development of implicit knowledge, employees' competencies can be determined and made available in skill management systems and expert directories.
- Collaboration: This category comprises systems that support collaboration among employees, e.g., systems for communication, workflow management, and virtual communities as well as groupware systems.

- Composition: This category comprises systems for the structuring, structured presentation, and location of knowledge, e.g., enterprise information retrieval systems and portals.

ERP systems as well as transaction systems are highly relevant to CRM, because they process and store structured information on customers, e.g., customer and contract master data, as well as business transactions. On the one hand, this data is needed in the CRM analysis processes to obtain a complete picture of a customer. On the other hand, the CRM delivery and support processes need access to all company information concerning a specific customer to address him individually and to better address his needs.

\section{Research Methodology}

Our approach is based on a case study method by Senger and Österle, which is an adaptation of Yin's methodology [23] developed to analyze business transformation projects [18].

\subsection{Case sites}

The research data was collected from June to October 2003 in a study of three Swiss and German financial services companies (Table 1). Site selection was based on a willingness to cooperate [23] and on the role and use of customer knowledge in CRM. To ensure comparability, we focused on CRM in the retail banking segment of the respective companies.

\subsection{Data collection}

In all three cases, data was collected through semistructured interviews with key informants and a document analysis of annual reports, organizational charts, and system charts. Senger and Österle's case study method [18] provided the structure for the central semi-structured interviews. The interview questions were based on the levels strategy, process and system and may be summarized as follows:

- Strategy: What are the strategic objectives and concepts employed in the CRM initiatives? 
- Process: What are the relevant CRM processes and implementation measures?
- System: Which information systems are used to support the CRM processes implemented?

Table 1. Overview of case sites. ${ }^{1}$

\begin{tabular}{|l|l|l|l|}
\hline & Investment Bank & Regional Bank & Universal Bank $^{2}$ \\
\hline Description & $\begin{array}{l}\text { German investment fund } \\
\text { management company }\end{array}$ & A regional Swiss universal bank & $\begin{array}{l}\text { A globally-active Swiss financial } \\
\text { services company }\end{array}$ \\
\hline Business segments & $\begin{array}{l}\text { Investment funds, asset } \\
\text { management }\end{array}$ & $\begin{array}{l}\text { Corporate/ retail/ private banking } \\
\text { insurance }\end{array}$ & $€ 644$ billion \\
\hline Total assets & $€ 100$ billion & $€ 9$ billion & ca. 75,000 \\
\hline Employees & ca. 2,000 & ca. 750 & ca. 3 million \\
\hline Customers & ca. 4 million & ca. 230,000 & Customer Profitability Management \\
\hline Type of CRM approach & $\begin{array}{l}\text { Customer Satisfaction } \\
\text { Management }\end{array}$ & Customer Contact Management & \\
\hline
\end{tabular}

\subsection{Data analysis}

We used a two-stage strategy for data analysis [23]. During the first stage, the within-case analysis of the data from each case study site was undertaken. The objective was to build an explanation of the case, using a cycle of deduction and induction. The validity of the data was ensured through multiple sources of evidence, reviews of case interpretations by interviewees and a chain of evidence provided by the case data.

The second stage involved the cross-case analysis of the data, thus locating and examining similarities and differences across the three cases. In the process, the companies' different focus, collection and use of customer knowledge was taken into account. The objective was to identify similarities and differences on strategy, process and system levels that resulted from a different role and importance of customer knowledge in CRM and vice versa.

\section{Types of CRM approaches in the Financial Services Industry}

The CRM reference architecture described in the previous section provides a means of describing the different CRM implementations on the process and system levels in the three cases. As a result of our case study research, we identified three distinct types of CRM approaches that differ on the strategy, process, and system levels and in the importance and use of customer knowledge: CRM as Customer Satisfaction Management, CRM as Customer Contact Management, and CRM as Customer Profitability Management. We describe each type and present case examples in line with the CRM architecture. Complete case descriptions are beyond the scope of this paper.

\subsection{CRM as Customer Satisfaction Management}

CRM as Customer Satisfaction Management aims at high customer satisfaction by offering customers a high quality of service and proximity. These objectives are often supported by knowledge management systems, in order to improve service quality and accelerate processes and problem solutions. Detailed knowledge on customers is not, however, necessary, because Customer Satisfaction Management does not distinguish between individual customers. Rather, the measures implemented are applied to all customers equally.

For example, the application of a customer typology within the scope of campaign management facilitates the precise addressing of customer needs. Within sales management, a counseling methodology can guarantee the systematic discovery of customer needs and the offering of suitable products to improve the counseling quality. Furthermore, within service management, service level agreements (SLA) can be used to specify maximum response times. Another

\footnotetext{
${ }^{1}$ Approved cases are available at www.iwi.unisg.ch.

${ }^{2}$ The names of these companies were changed due to non-disclosure agreements.

${ }^{3}$ A universal bank is a bank that offers a comprehensive range of banking products.
} 
example is the offering of accommodating solutions to dissatisfied customers in the complaint management process. This requires employees to be sufficiently empowered to freely decide on concessions during a conversation with a customer. Knowledge management systems can be a means of systematic support for Customer Satisfaction Management, because they enable the swifter processing of customer inquiries.

Customer Satisfaction Management therefore primarily covers the CRM delivery processes of the CRM architecture. The implemented measures are therefore mostly of an organizational nature. $K M$ systems are primarily used for process support on the system level.

Investment bank has an exemplary implementation of CRM as Customer Satisfaction Management. The objectives of the CRM at Investment Bank are to exploit the customer potential of its distribution partners and to increase brand recognition. Since the bank's products are mainly distributed to partner companies, it has little direct contact with end customers. To increase brand recognition and customer satisfaction with the services offered, Investment Bank uses a selfdeveloped customer typology, which helps to determine a customer's investor type. The typology is used within Investment Bank's campaign management process and within the distribution partners' sales management processes. Within the campaign management processing, the addressing of customers is adapted according to each investor type. Moreover, part of the customer magazine is designed to address the different investor types. To improve the distribution partners' sales management processes, Investment Bank can provide detailed descriptions of proposed counseling strategies and the recommended behavior when counseling each investor type. Customer consultants can determine the investor type at the start of a counseling interview by using seven simple and impersonal questions like "How important is flexibility of investments for you?" The objective of the typology is customer counseling, oriented toward customer needs, in order to achieve long-term customer satisfaction with the purchased products.

A call center handles the service management process of Investment Bank with SLAs guaranteeing a high quality of service. Furthermore, a content management system enables a competent and quick response to customer inquiries regarding complex bank products. The call center is used by end- customers as well as the customer consultants of the distribution partners. Regular opinion polls measure customer satisfaction.

The objective of the CRM implementation at Investment Bank was the improvement of customer satisfaction. Investment Bank therefore only differentiates between customers on the basis of the customer typology. Since it favors long-term customer satisfaction, Investment Bank forgoes measures for short-term sales increase.

\subsection{CRM as Customer Contact Management}

CRM as Customer Contact Management aims at reducing costs by improved process efficiency and the use of media-based communication channels. Integrated information and communication technology is used to maintain or even increase service quality by realizing shorter cycle times. Moreover, Customer Contact Management aims to provide customers with a consistent interface across all communication channels.

A prerequisite for realizing these goals is the collection and provision of relevant customer data at all customer contact points. Besides the customer master data, employees with customer contact also record the contact history, topics discussed, customer requirements, and "soft" customer data such as hobbies, interests, and preferences. Transparency between the enterprise and customers is thus established across all interactions. Standardized input formats and categories guarantee the usability of data for automatic data analysis. However, data analysis plays a secondary role. The relevant processes of Customer Contact Management are campaign management, sales management, service management, and complaint management. In these processes, customer data is collected and also utilized. Operational CRM systems support the collection of customer data and the management of customer contacts. Collaborative CRM systems support the integration and synchronization of different communication channels within the scope of multi-channel management. Besides achieving shorter cycle times, the use of media-based communication channels also allows cost reductions.

Regional Bank has an exemplary implementation of CRM as Customer Contact Management. The objectives of CRM at Regional Bank were the improvement of the proximity to customers and the realization of cost-cutting opportunities through 
information systems. Within the scope of campaign management, Regional Bank carries out intermittent database queries to support the planning of productoriented campaigns. These queries result in customer lists that are forwarded to the responsible customer consultant in a branch office, or to the contact center for processing. Because the branch offices and contact center's CRM systems are integrated, the contact center can launch product campaigns and transfer the leads generated to the calendars of branch office consultants. The consultants counsel the customers within the sales management process. By using a contact center, activity-based costs are reduced and branch office consultants have more time to counsel customers. Therefore, multi-channel management and integrated information systems not only reduce costs, but also improve proximity to customers. These goals are additionally pursued by the contact center's central handling of service and complaint management processes. Moreover, operational CRM systems support customer and contact management and thus decrease the time that consultants spend on administrative tasks.

Regional Bank has built its infrastructure for Customer Contact Management step-by-step over a period of five years: a paper-based counseling methodology, an ERP system, an operational CRM system, and a data warehouse. The more components Regional Bank added and the better they were integrated, the greater the benefits were that the bank achieved.

The example of Regional Bank shows how the employment of information systems within the scope of Customer Contact Management can lead to increased proximity to customers, more efficient processes, as well as cost reductions.

\subsection{CRM as Customer Profitability Management}

The strategic objective of CRM as Customer Profitability Management is to develop long-lasting, profitable relationships with customers. This is achieved by increasing customer loyalty and exploiting the potential of the customer base.

In Customer Profitability Management, a company has to identify and nurture profitable customer relationships. Unprofitable relationships have to be made profitable or abandoned. Extensive data analysis that will not only differentiate between profitable and unprofitable customers, but will also target product offers to individual customers, can support this task. In a first step, a company has to implement loyalty management, customer profiling, and customer scoring processes. Customer profiling develops a profile for each customer, which forms the foundation of long-term strategic customer planning. Customer scoring, moreover, discovers individual cross- and up-selling opportunities. The results are transferred to the campaign and sales management process.

This CRM approach employs methods for the monetary assessment of customer relationships to establish equilibrium between investments in customer relationships and realized profits. Besides customer assessment, precise definition and control of CRM measures in the context of loyalty management are necessary. Within performance management, the profitability of CRM measures and the development of customer segments are monitored. A data warehouse and other analytic CRM systems make up the core of the information systems infrastructure. As in Customer Contact Management, operational and collaborative CRM systems enable employees' efficient management of customer data, communication, and contacts.

Besides the CRM delivery processes, Customer Profitability Management therefore also covers the CRM support and analysis processes of the CRM architecture. In particular, a closed knowledge loop is established in this CRM approach. Relevant customer knowledge is collected at all customer contact points and then analyzed. The results are disseminated and explained through detailed instructions to the employees at the customer contact points.

On the system level, operational and collaborative CRM systems as well as analytical CRM systems support the CRM processes. Moreover, ERP and transaction systems serve as data sources for the data warehouse and analytical systems.

Universal Bank has an exemplary implementation of CRM as Customer Profitability Management. The objectives of CRM at Universal Bank are long-term customer retention and exploitation of the potential of its customer base.

Universal Bank uses the results of customer scoring to build the foundation for the campaign management process. The bank performs a data mining analysis for each product-oriented campaign to identify those customers who are most likely to buy the product. Only the most likely customers are selected as recipients of a campaign. Moreover, 
within the campaign management process, Universal Bank calculates the net present value for each campaign and makes an investment decision on this basis. Depending on the product offered and the customer selected, a recipient is either transferred to a customer consultant in a branch office, to the call center, or to the mailing department. This is done by email, or by an entry in the operational CRM system. The sales and service management processes do not differ from the processes in Customer Contact Management. Besides a customer's profitability, his development and potential for the enterprise play an important role. Loyalty management determines these factors and actively controls them. Universal Bank uses a matrix for the classification of its customers according to their loyalty and value to the enterprise. It also uses this matrix to monitor customer migrations between customer segments as defined in the matrix. Individual product offerings on the basis of the analysis make the active control of migration possible. According to Universal Bank it achieved a return on investment (ROI) of investments in analytical CRM infrastructure and employee training within two years.

The objectives of CRM implementation at Universal Bank are the exploitation of its customer potential and the active development of customer relationships. The implementation of Customer Profitability Management started with the construction of a company-wide data warehouse. Using data mining and OLAP systems, the bank generates customer profiles and sales opportunities, and furthermore monitors and plans the long-term development of each individual customer relationship. KM helps to support the dissemination and correct use of customer knowledge gathered in the analytical support processes.

Table 2. Types of CRM approaches.

\begin{tabular}{|c|c|c|c|}
\hline Type & $\begin{array}{c}\text { Customer Satisfaction } \\
\text { Management }\end{array}$ & $\begin{array}{c}\text { Customer Contact } \\
\text { Management }\end{array}$ & $\begin{array}{c}\text { Customer Profitability } \\
\text { Management }\end{array}$ \\
\hline $\begin{array}{l}\text { Strategic } \\
\text { Objectives }\end{array}$ & Improvement of customer satisfaction & Process efficiency and cost reduction & $\begin{array}{l}\text { Customer retention and exploitation of } \\
\text { customer potential }\end{array}$ \\
\hline $\begin{array}{l}\text { Processes } \\
\text { implemented }\end{array}$ & CRM delivery processes & CRM delivery processes & $\begin{array}{l}\text { CRM delivery, analysis, and support } \\
\text { processes }\end{array}$ \\
\hline $\begin{array}{l}\text { Systems } \\
\text { implemented }\end{array}$ & $\begin{array}{ll}\text { - } & \text { Integrated CRM system not } \\
\text { necessary } \\
\text { - } \text { KM systems }\end{array}$ & $\begin{array}{l}\text { - Collaborative and operational } \\
\text { CRM systems }\end{array}$ & $\begin{array}{l}\text { Collaborative, operational, and } \\
\text { analytical CRM systems } \\
\text { - KM systems } \\
\text { - Use of customer data from ERP } \\
\text { and transaction systems }\end{array}$ \\
\hline $\begin{array}{l}\text { Role of customer } \\
\text { knowledge and } \\
\text { major } \\
\text { characteristics }\end{array}$ & $\begin{array}{l}\text { Usage of general measures (e.g. } \\
\text { service level agreements (SLA), } \\
\text { customer counseling methods, } \\
\text { customer typologies) without } \\
\text { differentiation between customer } \\
\text { segments } \\
\text { - IT support is not essential } \\
\end{array}$ & $\begin{array}{l}\text { Collection of customer data for } \\
\text { efficient customer support } \\
\text { - IT support provides a single view } \\
\text { on customers at all customer } \\
\text { contact points } \\
\text { - Multi-channel management for } \\
\text { cost reductions }\end{array}$ & $\begin{array}{l}\text { Analysis of customer data to } \\
\text { develop different strategies and } \\
\text { up- and cross-selling opportunities } \\
\text { per customer (or customer } \\
\text { segment) } \\
\text { - Active development of customer } \\
\text { relationships }\end{array}$ \\
\hline $\begin{array}{l}\text { Implemented } \\
\text { processes and } \\
\text { systems (dark) } \\
\text { according to CRM } \\
\text { architecture (see } \\
\text { Figures 1\& 2) }\end{array}$ & Processes & 'rocesses & Processes \\
\hline
\end{tabular}

\subsection{Summary of findings}

The analysis of three case studies has shown that there are distinct types of CRM approaches in the financial services industry (Table 2). The types can be distinguished by the use of customer knowledge and CRM strategy, processes, and systems. They can be described using the CRM architecture.

\section{Conclusion and further research}

Building on previous research and comprehensive analysis of research literature, we developed a CRM reference architecture focused on the process and system levels. This architecture can be used for the description and classification of CRM approaches in companies. We furthermore analyzed CRM case studies in Swiss and German financial services 
companies and derived three types of CRM approaches in the financial services industry: Customer Satisfaction Management, Customer Contact Management, and Customer Profitability Management. We described each type, using the CRM architecture and a case example. The CRM architecture and types can be used as a structural framework in the analysis of CRM approaches in financial services companies, to compare the context and objectives with those of other enterprises, and to derive new strategies and objectives.

The small number of analyzed cases limits generalization. Therefore the types of CRM approaches we developed have to be further validated in empirical research, for example, using additional case studies.

Regarding further research opportunities, it would be interesting to analyze which environmental factors influence companies' respective CRM approach. Further research needs to evaluate which factors influence the type of CRM approach that a company should pursue.

\section{References}

[1] Alavi, M. and Leidner, D. E., "Knowledge Management and Knowledge Management Systems: Conceptual Foundations and Research Issues", MIS Quarterly, Vol. 25, No. 1, 2001, pp. 107-136.

[2] Davenport, T. H., Harris, J. G. and Kohli, A. K., "How Do They Know Their Customers So Well?" MIT Sloan Management Review, Vol. 42, No. 2, 2001, pp. 63-73.

[3] Day, G. S., Capabilities for Forging Customer Relationships, 2000.

[4] Garcia-Murillo, M. and Annabi, H., "Customer Knowledge Management", Journal of the Operational Research Society, Vol. 53, No. 8, 2002, pp. 875-884.

[5] Gebert, H., Geib, M., Kolbe, L. M. and Brenner, W., "Knowledge-enabled Customer Relationship Management - Integrating Customer Relationship Management and Knowledge Management Concepts", Journal of Knowledge Management, Vol. 7, No. 5, 2003, pp. 107-123.

[6] Geib, M. and Riempp, G., "Customer Knowledge Management", in: Abecker, A., Hinkelmann, K., Maus, H. and Müller, H.-J. (Eds.), Geschäftsprozessorientiertes Wissensmanagement [Business Process-oriented Knowledge Management], Springer, Berlin et al., 2002, pp. 393-417.

[7] Gronover, S., Multi-Channel-Management, Dissertation, University of St. Gallen, St. Gallen, 2003.

[8] Grönroos, C., "From Marketing Mix to Relationship Marketing: Towards a Paradigm Shift in Marketing", Management Decision, Vol. 32, No. 2, 1994, pp. 4-20.
[9] Ives, B. and Learmonth, G. P., "The Information System as a Competitive Weapon", Communications of the ACM, Vol. 27, No. 12, 1984, pp. 1193-1201.

[10] Kotler, P., Marketing Management, 11 ed., Prentice Hall, Englewood Cliffs, New Jersey, 2003.

[11] Österle, H., Business Engineering: Prozess- und Systementwicklung [Process and System Development], Springer, Berlin, 1995.

[12] Österle, H., "Geschäftsmodell des Informationszeitalters [Business Model of the Information Age]", in: Österle, H. and Winter, R. (Eds.), Business Engineering, Springer, Berlin, 2003, pp. 22-43.

[13] Payne, A. and Ryals, L., "Customer relationship management in financial services: towards informationenabled relationship marketing", Journal of Strategic Marketing, Vol. 9, No. 1, 2001, pp. 3-27.

[14] Peppard, J., "Customer relationship management (CRM) in financial services", European Management Journal, Vol. 18, No. 3, 2000, pp. 312-327.

[15] Peppers, D. and Rogers, M., The One to One Future Building relationships one customer at one time, Currency Doubleday, New York, 1993.

[16] Quintas, P., Lefrere, P. and Jones, G., "Knowledge Management: A Strategic Agenda", Long Range Planning, Vol. 30, No. 3, 1997, pp. 385 - 391.

[17] Schulze, J., Thiesse, F., Bach, V. and Österle, H., "Knowledge Enabled Customer Relationship Management", in: Österle, H., Fleisch, E. and Alt, R. (Eds.), Business Networking: Shaping Collaboration Between Enterprises, Springer, Berlin et al., 2001, pp. 135-152.

[18] Senger, E. and Österle, H., ProMet BECS - A Project Method for Business Engineering Case Studies, 2002.

[19] Shahnam, E., The Customer Relationship Management Ecosystem. Application Delivery Strategies Delta 724, http://www.metagroup.com/communities/crm/ads724.ht $\mathrm{m}$, 17.11.2003.

[20] Shaw, R. and Reed, D., Measuring and valuing customer relationships: How to develop the measures that drive profitable CRM strategies, Business Intelligence, London, 1999.

[21] Stauss, B. and Seidel, W., Beschwerdemanagement [Complaint Management], 3 ed., Hanser, München, 2002.

[22] Thompson, E., Davies, J. and Frey, N., Gartner's 2002 European CRM Survey: As Projects Progress, Challenges Abound. Gartner Strategic Analysis Report, Note No. R-17-6739, Research Report, Gartner, 2002.

[23] Yin, R. K., Case Study Research. Design and Methods, 3 ed., Sage Publications, London, 2002. 